\title{
Impact Of Leadership Styles On Employee Organizational Commitment
}

Sharon Clinebell, University of Northern Colorado, USA

Vida Škudienè, ISM University of Management and Economics, Lithuania

Renata Trijonyte, ISM University of Management and Economics, Lithuania James Reardon, University of Northern Colorado, USA

\begin{abstract}
This research study examines the relationship between transformational, transactional and passive/avoidant leadership styles and three dimensions of organizational commitment - affective, continuance, and normative in two subsidiaries of one multinational organization. The research findings revealed that transformational leadership has the strongest impact on affective commitment, although transactional leadership also affects affective commitment. Transformational leadership also has a significant positive affect on normative commitment. Transactional leadership has a significant positive affect on continuance commitment and positive/avoidant leadership has a significant negative affect on affective commitment.
\end{abstract}

Keywords: Organizational Commitment; Leadership

\section{INTRODUCTION}

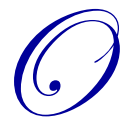

rganizational commitment is one of the constructs that has retained its importance throughout decades and, despite the extensive research done in the field, still draws a high level of attention due to its association with such preferred work attitudes as increased job satisfaction, higher performance, lower absenteeism and turnover intentions (Yousef, 2000). It has been generally recognized that organizational commitment is one of the major factors determining organizational performance and effectiveness (Lok \& Crawford, 1999, 2004).

In addition, as observed by Allen and Meyer (1990), a common link discussed in all conceptualizations of commitment is the one between organizational commitment and turnover, indicating that "employees who are strongly committed are those who are least likely to leave the organization". By contrast, it is assumed that less committed employees tend to leave their organizations more often and, in case of lack of alternatives, they may "emotionally or mentally "withdraw" from the organization" (Lok \& Crawford, 1999, p. 58; 2004, p. 321). In an earlier meta-analysis, Mathieu and Zajac (1990) also found support for the relationship between organizational commitment and turnover.

Yammarino and Dubinsky (1992) advocate an employee's perception of the immediate supervisor to be one of the major determinants of employee attitudes in the work place, including organizational commitment. This assumption prompts for a deeper examination of distinct leadership styles employed in the day-to-day leaderfollower relationship. A set of questions arises with respect to how distinct styles or behaviors employed by a leader affect the form and level of employee's commitment. Even though separately, leadership behavior and organizational commitment has been an object of research for decades, their mutual relationship received considerably less attention, especially with respect to distinct leadership behaviors and multi-dimensional approach to organizational commitment. As advocated by Meyer and Allen's $(1991,1997)$ building on principles of need, satisfaction and exchange, employees are more likely to willingly contribute to the success of the organization and remain employed longer when their needs are satisfied within the work place. The leader acting as the closest mediator in the employment environment is entrusted to ensure satisfied and committed employees. Thus, the leader should be very familiar with any impact his/her demonstrated behavior has on followers' perceptions towards the 
work place, or even the organization as a whole, and adapt his/her leadership behaviors in order to enhance followers' commitments. The purpose of this research is to examine the relationship between distinct leadership styles and separate dimensions of organizational commitment in two foreign subsidiaries of one multinational organization.

\section{Theory on Employee Organizational Commitment}

Although there are many differing definitions of organizational commitment (Meyer \& Allen, 1997; Dale \& Fox, 2008), Meyer and Allen $(1991,1997)$ have identified commonality in various definitions in that commitment is a psychological state that characterizes the employee's relationship with the organization and has implications for the decision to continue membership in the organization.

Meyer and Allen $(1990,1991,1997)$ noted that a distinction was made between attitudinal and behavior commitment. In the attitudinal approach, it is an attitude or a mind-set of employees that is measured in relation to either antecedents (conditions) or consequences of commitment (behavior). Meanwhile, in the behavioral approach, it is a course of action that plays an essential role as employees become committed specifically to that certain existing behavior, e.g. remaining employed in the organization, rather than to the organization itself and, as a consequence, tending to assimilate their attitudes accordingly with the prevalent perception of work experiences to keep it consistent and avoid cognitive dissonance (Meyer \& Allen, 1988, 1991, 1997). It is assumed that within the attitudinal perspective, behavior, as a consequence of commitment, can influence the conditions that affect the state of commitment, while behavioral perspective suggests that attitudes as an outcome of certain behavior may have an impact on a recurring occurrence of such behavior (Meyer \& Allen, 1991). The two approaches have both affected the conceptualizations of organizational commitment, to a great extent, and often the distinction can be viewed as blurred, depending on the interpretation of certain phenomena.

Continuing research in the field has led to an advanced understanding of the concept of organizational commitment by bringing into scope other forms of attachment that exist between employees and organizations. One of the most widely known and practically applied extensions of organizational commitment concept is that of Meyer and Allen (Meyer \& Allen, 1990, 1997; Lee et al, 2001; Meyer \& Herscovitch, 2001) who suggested a multidimensional concept resulting in three components of organizational commitment - affective, continuance, and normative. The scholars argue that affective, continuance, and normative commitment should always be treated as components or dimensions instead of distinct types of commitment, and they further contemplate that these components are being experienced by employees simultaneously, only to different extents (Meyer \& Allen, 1990, 1991, 1997). Meyer \& Allen (1991) also assert that even though the three components denote a certain psychological state of commitment, each is of a different nature. Meyer and Allen's work $(1988,1990,1991,1997)$ assumes that each of the three components develops as a consequence of different antecedents.

\section{Affective Commitment}

Employees with a strong affective commitment continue employment with the organization because they want to do so. This component is often treated as a predecessor of organizational commitment, in general, due to the fact that Porter, in his studies (Dubin, Champoux \& Porter, 1975), focused on a one-dimensional approach which is now being reflected upon as representing, namely, affective commitment. As initially suggested by Mowday, Steers, and Porter (1979), there can be four distinct groups of antecedents identified with respect to affective commitment 1) personal characteristics, 2 job characteristics, 3) work experiences, and 4) structural characteristics. The vast majority of attention in the research field has been devoted particularly to work experiences as it is believed to be mostly manageable within the organization in order to affect employees' commitments in the desired way (Meyer \& Allen, 1988).

\section{Continuance Commitment}

Employees whose primary link to the organization is based on continuance commitment remain because they need to do so. There are two factors identified that impact the development of continuance commitment. One is related to the volume of investments made and another is influenced by scarcity of alternatives. Becker's (1960) 
side-bet theory has placed a solid ground for evolution of this component as it elaborates that employees keep committed to a certain organization based on their time and effort spent for mastering specific skills and gaining experiences or social relationships that cannot be replicated with ease elsewhere and would require enormous investment to start over - in other words, "sunk costs" are taken into consideration to a great extent (Bučiūnienė \& Škudienè, 2008). Equally continuance commitment evolves under perceived lack of alternatives which forces an employee to remain in the organization.

\section{Normative Commitment}

Employees with a high level of normative commitment feel that they ought to remain with the organization. This is the component that has been questioned to have significant similarities with affective commitment, especially when validating the scales presented by Meyer and Allen $(1990,1991,1997)$. The antecedents of this dimension cover both prior and post employment experiences. Normative commitment, as an obligation to remain loyal to one organization, is capable of evolving much earlier than the actual employment takes place. Family values, cultural socialization, historical traditions, and many other external factors can influence the evolution of psychological state of obligation and a strong belief that one ought to be loyal to the organization. Of equal importance is the organizational socialization after having entered the organization - the different attitudes and values exhibited and believed in within the employment environment that can have impact on perceptions of a newcomer.

\section{The Full Range Leadership Model}

Bass (1990, 1999) developed the full range leadership model entailing transformational, transactional, and passive/avoidant dimensions or leadership styles. Bass also introduced the Multifactor Leadership Questionnaire (MLQ) to measure the full range leadership, which, according to Turner and Müller (2005), is the most widely used leadership measure. Bass' model encompasses nine factors or underlying leadership behaviors explaining each of the leadership styles derived from research studies by using the MLQ. There were numerous refinements made in the run of decades of research to reflect the findings of various analyses and improve the model.

\section{Transactional Leadership}

This type of leadership is being referred to as traditional and was named based on the argument that there are certain underlying transactions or bargains between managers and employees where followers are introduced to what certain behavior is expected from them in order to become entitled to the compensation or reward for their compliance to the postulated requirements. As Bass denoted in his overview of 20 years of research in the field, such a leader-follower relationship is based solely on self-interest and entails a cost-benefit exchange process (Bass, 1999). Based on Bass' model, there are certain techniques or behaviors used by a leader for goal attainment - 1) contingent reward and 2) management-by-exception active. Contingent reward represents the relationship based on punishments and rewards in return for expected performance, whereas management-by-exception active reveals observance for deviations in follower's performance and adequate repay (Flynn, 2009). As defined by Bass (1990, p. 20) when using contingent reward, "the leader gets things done by making and fulfilling promises of recognition, pay increases, and advancement for employees who perform well ... and contrary, employees who do not do good work are penalized."

A very important observation, though, is that the level to which the rewards or avoidance of penalties affect the followers depends on two conditions: 1) there must be a wish for rewards or avoidance of penalties from the follower's side and 2) a certain control or freedom of the leader towards awarding or punishing. Pay increases and promotions are most often dependant on internal policies and other factors, such as qualification of the follower or existing competition, while penalties are usually administered under certain breakage of regulations. As observed by Bass (1990, p. 20), "many an executive has found his or her hands tied by contract provisions, organizational politics, and inadequate resources." 


\section{Transformational Leadership}

Hater and Bass (1988) contemplate that under this kind of leadership, followers express high personal identification with their leaders and are determined to go beyond self-interest due to a commonly shared vision with their leaders. Followers are strongly motivated and constantly inspired to overachieve what is expected of them. Bass (1990) observes that transformational leadership "occurs when leaders broaden and elevate the interests of their employees, when they generate awareness and acceptance of the purposes and mission of the group, and when they stir their employees to look beyond their own self-interest for the good of the group" (p. 21). Under Bass' model, transformational leaders exhibit the following attributes or behaviors: 1) idealized influence-attributed, 2) idealized influence-behavior, 3) inspirational motivation, 4) intellectual stimulation, and 5) individual consideration. Idealized influence-attributed refers to high levels of leader's self-confidence which instills pride, respect, and trust in the leader (Flynn, 2009). This factor is the only one comprised of attribution items, while idealized influence-behavior represents a leader striving to promote his beliefs in an influential manner (Flynn, 2009). Inspirational motivation represents the ability of the leader to act as a role model and inspire subordinates to exert his/her efforts towards a shared vision. This factor was detached from the initial factor of charisma due to different behaviors implied and a belief that "a leader could provide a challenge and meaning through the use of simple words, slogans, symbols, and metaphors to generate acceptance of missions, without necessarily being charismatic" (Bass, 1999, p. 19). Intellectual stimulation covers a leader's ability to challenge the way the follower tends to think in the problemsolving process by encouraging him/her to take into consideration different perspectives and bring in new ways of making things happen. Finally, individual consideration reflects concern for subordinates to reach their full potential. It entails identifying individual needs and aspirations of each subordinate and indulging in coaching and training.

\section{Passive-Avoidant Leadership}

Transactional and transformational leadership styles represent the active leaders who are keen on preventing problems; meanwhile, there are often occurances of indifferent leaders who act passively towards solving potential problems, reacting only when they become chronic or, in general, tend to avoid responsibility in supervising and decision-making. The passive leader is represented by the management-by-exception passive factor or behavior which reflects a leader who is "waiting for problems to arise before taking corrective action" (Bass, 1999, p. 11). Meanwhile, lack of leadership or non-leadership style, as suggested by Yamarino and Bass (1990), is referred to as laissez-faire and is highly contrasted to the active forms of leadership. Such leaders abdicate their overall responsibilities and keep themselves at a distance from the problems with which their followers deal.

The fact that so much attention has been paid to the concept of leadership, and various attempts have been made to measure the effectiveness of leaders, gives a clear indication of its influential relationship towards performance of the organization. As observed by Lok and Crawford (2004, p. 324), "leadership contributes significantly in the success and failure of an organization."

Boehnke et al. (2003) noted research by Kirkpatrick and Locke (1996) and Hunt and Schuler (1976) which found that transformational and transactional leadership was mostly reported to have positive correlations to individual performance of the follower (Howell and Avolio, 1993), while laissez-faire revealed mixed results, including negative (Bass \& Avolio, 1990) and non-correlation (Podsakoff et al., 1984). Bass et al (2003, p. 215) denoted that "earlier research on transformational leadership has shown that it augments transactional leadership in predicting performance", though Bass himself was not able to confirm the differences between transformational and transactional leadership with respect to predicting unit performance. There have also been positive relationships found between the perceived transformational leadership style and democratic leadership style and subordinates' work attitudes such as job satisfaction (Savery, 1994; Medley \& Larochelle, 1995; Emery \& Barker, 2007). Others, such as Ozaralli (2003), have found contribution of transformational leadership on subordinate's empowerment and team effectiveness. With respect to nonprofit or voluntary organizations, active leadership forms, such as transformational leadership style and management-by-exception active, have a positive relationship with positive emotions such as "joy, pride, admiration, and enthusiasm" (Rowold \& Rohmann, 2009, p. 280). Stronger correlations between transformational leadership style and leader's rated effectiveness, compared to transactional leadership style, were observed in the voluntary sector giving valuable insights to relationships beyond pure 
economic business (Rowold \& Rohmann, 2009). In addition, some scholars attempted to identify impact of different leadership behaviors on negative organizational outcomes, such as staff retention, and one of the correlations discovered is that with management-by-exception (Kleinman, 2004).

Overall, a number of research studies are conducted with respect to leadership styles and their differential impact on organizational outcomes and subordinates' attitudes in the work place, which is a clear indication of its persistent importance due to its perceived contribution to success of the organization.

\section{Relationship between Organizational Commitment and Leadership Styles}

Numerous empirical studies have confirmed certain leadership styles to have impact on development of separate dimensions of organizational commitment. The general trend is supported that certain relationships underlie between different leadership styles and organizational commitment, though the results are not entirely consistent.

Lok and Crawford (1999) observed significant correlations between consideration leadership style and commitment, while commitment's relation to initiating structure leadership style was lower, though still positive. Dale and Fox (2008) observed similar results. However, although a more recent study of Lok and Crawford (2004) similarly revealed a significant correlation between consideration leadership style and commitment, commitment was not found to have statistically significant correlation with initiating structure leadership style.

Yiing and Bin Ahmad (2009) examined the relationships between affective commitment and such leadership behaviors as participative, directive, and supportive with respect to moderating effects of organizational culture. All three leadership behaviors were found to have positive and significant relationship to affective commitment of employees.

There have been many studies aimed at examining relationships, particularly between transformational/transactional or laissez-faire leadership styles and organizational commitment (Avolio, Zhu, Koh, \& Bhatia, 2004; Bučiūnienè and Škudienė, 2008; Dunn, Dastoor \& Sims, 2012; Emery and Barker, 2007; Limsila and Ogunlana, 2007; Lo et al., 2010; Joo, Yoon and Jeung, 2012; Rehman, Shareef, Mahmood \& Ishaque, 2012; Walumbwa, Wang, Lawler \& Shi, 2004). As Geijsel et al. (2003, p. 229) denoted reflecting upon work of Yukl, "virtually all theoretical treatments of transformational leadership claim that, among its more direct effects, are employee motivation and commitment, leading to the kind of extra effort required for significant organizational change". Emery and Barker (2007) reported a moderate positive correlation between all factors of transformational leadership style, as well as contingent reward representing transactional leadership style and affective commitment; meanwhile, the second factor of transactional leadership - management-by-exception, though still not distinguished to active and passive - showed a negative correlation with affective commitment. Limsila and Ogunlana (2007) have found that only transformational leadership style correlated to affective commitment while no significant correlations were observed between transactional, laissez faire leadership styles and affective commitment.

Dun, Dastoor, and Sims (2012) found a positive relationship between transformational leadership and affective and normative commitment, but no significant relationship between transformational and continuance commitment. Avolio, et al. (2004) also found a positive relationship between transformational and organizational commitment. They also found that psychological empowerment and structural distance may be moderators in this relationship. Joo, Yoon, and Jeung (2012) found a positive relationship between transformational leadership and organizational commitment. In particular, they found that vision articulation, group goal promotion, and intellectual stimulation were significant predictors of organizational commitment. Rehman et al. (2012) found that while both transformational and transactional leadership impact organizational commitment, transformational leadership had a greater contribution to the level of organizational commitment. Walumbwa et al. (2004) also found a positive relationship between transformational leadership and organizational commitment. They also found that this relationship is partially mediated by collective efficacy.

Bučiūnienè and Škudienè (2008), as well as Lo et al. (2010), examined the relationship between full-range leadership styles and separate dimensions of organizational commitment advancing from analyzing effects of leadership styles on organizational commitment as a one-dimensional construct, but striving to examine the impact 
of distinct leadership styles on separate dimensions of organizational commitment; namely, affective, continuance, and normative. In a Lithuanian context, Bučiūnienè and Škudienè (2008) were able to observe relatively similar positive correlations between both transformational and transactional leadership styles with respect to affective and normative commitment dimensions, even though of less significance in transactional leadership relations. Meanwhile, they also found that laissez-faire correlated negatively to affective commitment. In a Malaysian context, dimensions of transformational leadership were found to be predictive of all dimensions of organizational commitment, while no significant relationship was observed between dimensions of transactional leadership dimensions with respect to affective, continuance and normative commitment (Lo et al, 2010). The results obtained in various empirical studies do not show entire consistency with respect to relationship between leadership styles and organizational commitment which therefore prompts further research.

\section{HYPOTHESES DEVELOPMENT}

Recent empirical studies have claimed that transformational leadership has, in general, a higher impact on organizational commitment than does transactional leadership style (Avolio et al., 2004; Bučiūnienè \& Škudienė, 2008; Emery \& Barker, 2007; Joo, Yoon, \& Jeung, 2012; Limsila \& Ogunlana, 2008; Lo et al, 2010; Rehman et al., 2012; Walumbwa et al., 2004). Despite the fact that most of the studies examining a relationship between leadership styles and organizational commitment were conducted using Porter's one-dimensional measure, which can only be assumed to represent dimension of affective commitment, a few studies reported their results based on a multidimensional measure revealing transformational leadership style to have a stronger impact on affective commitment than transactional leadership style (Bučiūnienė \& Škudienė, 2008; Lo et al, 2010). According to Meyer \& Allen (1997, p. 46), who focused on various antecedents of distinct dimensions of organizational commitment, "affective commitment to the organization is stronger among employees whose leaders allow them to participate in decisionmaking ... and who treat them with consideration ... and fairness". These characteristics can be compared to at least two underlying behaviors of transformational leadership style; namely, intellectual stimulation and individual consideration. Based on these observations, the first hypothesis to be tested is proposed as follows:

Hypothesis 1: Transformational leadership style positively affects the level of affective commitment.

As observed in most of the studies (Meyer \& Allen, 1997; Bučiūnienè \& Škudienė, 2008; Lo et al, 2010), normative commitment scale tends to show similar patterns of correlations with antecedents to the ones observed within affective commitment scale. Only the latter, in most cases, reveals stronger relationships. Debates appear in the leadership literature suggesting that the feelings of emotional attachment and obligation are often not independent of one another. Specifically, transformational leadership style is most often found to have an impact on normative commitment (Bučiūnienė \& Škudienè, 2008; Lo et al, 2010). Based on this, the second hypothesis is as follows:

Hypothesis 2: Transformational leadership style positively affects the level of normative commitment.

Meyer \& Allen (1997) identified "psychological contract" between an employee and organization as one of the hypothesized antecedents to organizational commitment. A distinction, however, is made between "transactional and relational" forms of psychological contract which are interpreted differently, suggesting each having impact on separate dimensions of organizational commitment - transactional is treated as more objective, evolving from economic exchange and thus more relevant for development of continuance commitment, while relational contract is based on general social exchanges and has more impact on development of normative commitment (Meyer and Allen, 1997). The cost-benefit approach of transactional type of psychological contract with the organization is similar to transactional leadership style, indicating "relationship...(when) followers' material and psychic needs are satisfied in return for expected work performance" (Sarros \& Santora, 2001, p. 388). Meanwhile, transformational leadership, in contrast, "stirs...(the) employees to look beyond their own self-interest for the good of the group" (Bass, 1990, p. 21) and raise their willingness to exert extra effort which exceeds merely pure economic exchange. Building on the synthesis of these theoretical considerations, another proposed hypothesis is:

Hypothesis 3: Transactional leadership style positively affects the level of continuance commitment. 
Passive/avoidant leadership style is described as representing "maintenance of status quo, poor communication...lack of confidence... (or even) avoidance and abdication of responsibility" (Sarros \& Santora, 2001, p. 389-390). This type of leader behavior reveals a lack of touch with followers and is assumed to have no impact, or even a negative one, on the most positive dimension of organizational commitment; namely, affective (Limsila \& Ogunlana, 2008; Bučiūnienè \& Škudienè, 2008). Based on the negative definitions of passive/avoidant leadership representing leader's indifference towards the followers, the following hypothesis is as follows:

Hypothesis 4: Passive/avoidant leadership style negatively affects the level of affective commitment.

\section{METHODOLOGICAL APPROACH}

\section{Sample and Data Collection}

The primary data in this empirical study were collected from two subsidiaries of one multinational enterprise operating in the IT industry, one of which is located in Vilnius, Lithuania, and the other in the capital of a country in central Europe, which cannot be revealed due to a confidentiality agreement with the organization. Hereinafter, both shall be referred to as 'the MNE' and 'the foreign subsidiary", respectively.

The survey questionnaire measured transformational, transactional, and passive/avoidant leadership styles, and dimensions of organizational commitment, specifically affective, continuance and normative. The wide international presence of the MNE has led to the institutionalization of the English language as the official language within the MNE. Based on the fact that assessment of English language skills is included in recruitment procedure as one of mandatory selection criteria for all employees of the MNE, it was assumed that all existing employees participating in the survey have sufficient English language skills to complete the survey questionnaire entailing items formulated in English; therefore, it was decided that no translation is required into either of the languages representing both subsidiaries. Not having the questionnaire translated also mitigated any translation issues that might arise.

After being pilot tested, the final version of the self-completion survey questionnaire was distributed to all employees as a hard copy, along with a self-addressed envelope to ensure a high level of anonymity. All participants responded on a voluntary basis and were guaranteed that their responses would remain confidential. Along with the physical distribution of the survey questionnaires, an internal introduction email, providing a short briefing of the intent and scope of the research, was sent directly to managers in Vilnius, requesting their support and further distribution within respective teams. Meanwhile, in the foreign subsidiary, a top-down approach was chosen in order to ensure a higher response rate, and the introduction email was forwarded by the Managing Director further into the organization. A reminder was sent within one week's time encouraging participating in the survey. Both subsidiaries were given 10 days to return the sealed envelopes in the special drop-boxes strategically based at the most visited places - the reception and kitchen areas.

A total of 359 questionnaires were distributed - 159 in Vilnius and 200 in the foreign subsidiary based on different head count numbers. All permanent employees of the two subsidiaries were sampled, including both fulltime and part-time. A total of 194 questionnaires were returned - 118 in Vilnius and 76 in the foreign subsidiary, out of which two and eight, respectively, were incomplete and thus treated as non-usable. A total of 184 questionnaires were used in the analysis, which constitutes a response rate of 51\% for the total sample and $73 \%$ and $34 \%$ in Vilnius and the foreign subsidiary groups, respectively. As expected, the higher response rate was observed in Vilnius which can be explained by the fact that one of the authors is an employee of this particular subsidiary and was able to proactively coordinate activities, while in the foreign subsidiary, the process was coordinated remotely with the help of local colleagues.

\section{Research Instrument}

The survey questionnaire was comprised of 63 questions in total, 24 of which were devoted to measure dimensions of organizational commitment, 34 measured leadership styles and underlying behaviors, and five additional questions covered demographic information. 


\section{Measure of Organizational Commitment}

The first part of the survey questionnaire measuring organizational commitment dimensions was slightly adapted from the OCQ developed by Meyer and Allen (1990). Based on the pilot study, a few minor changes have been made in two out of 24 items by employing synonyms for two English words that had been reported to be more difficult to understand for non-native speakers after the pilot survey ('scarcity' replaced by 'lack'; 'sensible' replaced by 'important').

\section{Measure of Leadership Styles}

The second part of the survey questionnaire measuring leadership styles and their underlying behaviors was adapted from Multifactor Leadership Questionnaire - MLQ-Form 5X Short - originally introduced and later reexamined, to a wide extent, by Bass and Avolio (1999). A new leadership style named 'Passive/avoidant' was formed which combines management-by-exception passive and laissez-faire sub-scales. Two of the items were adapted in order to increase understandability for non-native English speakers ('instills pride in me' replaced by 'I am proud of'; 'mobilizes' replaced by 'emphasizes'). The employees are asked to rate their direct day-to-day manager, who varies depending on the respondent, for example, it can be a team leader, a functional manager or a managing director subject to the type of functions undertaken by the rater.

\section{Demographical Items}

The last part of the survey questionnaire was devoted to demographical information. In total, five multichoice questions were presented: 1) interaction with direct manager - face-to-face or remote, 2) job functions administrative, leading, technical or other, 3) job tenure, 4) age and 5) gender.

\section{RESULTS}

Demographic data were gathered from the respondents. Sixty-three percent of the respondents were from the Vilnius location. Gender was approximately even with 50\% males, $47 \%$ females, and 3\% unspecified. Forty-six percent of employees are 26-30 years old. The next largest group was less than 25 years old with $32 \%$, followed by $31-35(13 \%), 36-40(2 \%)$, over $41(3 \%)$, with $4 \%$ of respondents not specifying their age. Forty-three percent of employees had technical job functions, $24 \%$ were administrative, $11 \%$ were classified as leading, $16 \%$ were classified as other, and $6 \%$ did not specify their job function. Eighty-three percent had face-to-face interaction with their managers, $10 \%$ had remote interaction, and $7 \%$ did not specify the mode of interaction with their managers. With respect to job tenure, a relatively high number of responents (28\%) have worked for less than a year. Forty-two percent have job tenure between 1 and 2 years and $22 \%$ of respondents represent the most experienced part of the organization having job tenure between two and three years.

The results reveal that transformational leadership style is the most dominant along both subsidiaries, according to ratings of employees. Transactional leadership style is used less often compared to transformational, while passive/avoidant leadership is identified less when compared to the other types of leadership styles.

Pearson's correlation coefficient was used to examine the relationship between leadership styles and employee organizational commitment. These results, as well as means, standard deviations, and Cronbach alphas, are shown in Table 1. Both transformational and transactional leadership styles have been found to correlate with all dimensions of organizational commitment to various degrees. Only passive/avoidant leadership style revealed no significant relationship to either continuance or normative dimensions of commitment and did show a significant negative correlation $\left(\mathrm{r}^{2}=-0.296, \mathrm{p}<.001\right)$ to transformational leadership. 
Table 1: Measures

\begin{tabular}{|ll|c|c|c|c|c|c|c|c|}
\hline & \multicolumn{1}{|c|}{ Variable } & Means & SD & $\mathbf{1}$ & $\mathbf{2}$ & $\mathbf{3}$ & $\mathbf{4}$ & $\mathbf{5}$ & $\mathbf{6}$ \\
\hline 1. & Affective Commitment & 5.50 & 1.60 & $(0.747)$ & & & & & \\
\hline 2. & Continuance Commitment & 5.42 & 1.77 & $.187^{* *}$ & $(0.684)$ & & & & \\
\hline 3. & Normative Commitment & 5.17 & 1.76 & $.344^{* * *}$ & $.284^{* * *}$ & $(0.613)$ & & & \\
\hline 4. & Transformational Leadership & 5.93 & 1.65 & $.325^{* * *}$ & $.198^{* *}$ & $.310^{* * *}$ & $(0.936)$ & & \\
\hline 5. & Transactional Leadership & 6.17 & 1.76 & $.345^{* * *}$ & $.330^{* * *}$ & $.391^{* * *}$ & $.751^{* * *}$ & $(0.799)$ & \\
\hline 6. & Passive/Avoidant Leadership & 4.41 & 1.60 & $-.296^{* * *}$ & -.013 & .011 & $-.470^{* * *}$ & $.300^{* * * *}$ & $(0.733)$ \\
\hline
\end{tabular}

Note: Cronbach alphas are on the diagonal. ${ }^{*} \mathrm{p}<.05 ;{ }^{* *} \mathrm{p}<.01 ;{ }^{* * *} \mathrm{p}<.001$

To test the hypotheses, regression models were developed where each type of organizational commitment was the dependent variable in separate regression models. Each type of leadership was the independent variable in each regression model. Hence, the models were as follows:

Affective Commitment $=\mathrm{B}_{1}$ Transformational $+\mathrm{B}_{2}$ Transactional $+\mathrm{B}_{3}$ Passive/Avoidant

Continuance Commitment $=\mathrm{B}_{1}$ Transformational $+\mathrm{B}_{2}$ Transactional $+\mathrm{B}_{3}$ Passive/Avoidant

Normative Commitment $=\mathrm{B}_{1}$ Transformational $+\mathrm{B}_{2}$ Transactional $+\mathrm{B}_{3}$ Passive/Avoidant

The results of the regression analyses are shown in Table 2.

Table 2: Regression Analysis Results

\begin{tabular}{|l|c|c|c|c|}
\hline & Transformational & Transactional & Passive/Avoidant & R2/F-value \\
\hline Affective Commitment & $0.296^{* *}$ & $0.247^{*}$ & $-0.201^{* *}$ & $0.160^{* *} / 11.447$ \\
\hline Continuance Commitment & $0.199^{* *}$ & $0.438^{* * *}$ & 0.084 & $0.119^{* * *} / 8.077$ \\
\hline Normative Commitment & $0.31^{* * *}$ & $0.197^{*}$ & 0.139 & $0.178^{* *} / 13.025$ \\
\hline
\end{tabular}

$\mathrm{p}<.05 ;{ }^{* *} \mathrm{p}<.01 ;{ }^{* * *} \mathrm{p}<.001$

All leadership styles were found to have a significant impact on affective commitment to varying levels. As predicted in Hypothesis 1, transformational leadership had a significant positive effect on affective commitment $\left(\mathrm{r}^{2}=\right.$ 0.296, $\mathrm{p}<.001)$. Therefore, Hypothesis 1 is supported. Transactional leadership was also shown to have a significant positive effect of affective commitment to a lesser degree $\left(\mathrm{r}^{2}=0.247, \mathrm{p}<.05\right)$. Passive/avoidant leadership had a significant negative effect on affective commitment $\left(r^{2}=-0.201, p<.01\right)$. Thus, Hypothesis 4 was supported.

The information presented in Table 2 shows that transformational leadership had a significant positive effect on normative commitment $\left(\mathrm{r}^{2}=0.310, \mathrm{p}<.001\right)$, providing support for Hypothesis 2. Transactional leadership also had a significant positive effect on continuance commitment $\left(r^{2}=0.438, p<.001\right)$. Thus, Hypothesis 3 is supported.

\section{DISCUSSION}

The empirical study conducted in two foreign subsidiaries of the MNE examined the relationship between transformational, transactional, and passive/avoidant leadership styles and dimensions of organizational commitment; namely, affective, continuance, and normative. Both transactional and transformational leadership styles were found to have relationships with all dimensions of organizational commitment to varying extents, while passive/avoidant leadership style showed a significant negative correlation with affective commitment dimension only. As predicted, transformational leadership had a stronger impact on affective and normative commitment levels, while transactional leadership had a stronger impact on continuance commitment. These findings are congruent with the findings of many studies discussed earlier.

Similarly to the relationship between both transformational and transactional leadership styles and affective commitment, both leadership styles positively affected normative commitment, with transformational also having a 
stronger impact than transactional. Normative commitment, as discussed in development of the hypotheses section, is often hardly distinguishable from affective commitment, in practice, though theoretical justifications differ for both dimensions. The results obtained in this study confirm previous empirical findings where both transformational and transactional leadership styles correlated with normative commitment (Bučiūnienè \& Škudienè, 2008). As observed by Meyer \& Allen (1997), the two scales of commitment - affective and normative - tend to have similar relations with the same antecedents. "The correlations involving the affective commitment scale, however, tend to be somewhat stronger than those involving the normative commitment scale." (p. 122)

The study also found that continuance commitment is more impacted by transactional leadership style compared to transformational. As significantly more attention was given to affective commitment since its introduction as a one-dimensional construct, antecedents of both normative and continuance commitment received considerably less attention. Only a few studies report the relationship, albeit weak, between transactional leadership and continuance commitment (Bučiūnienè \& Škudienè, 2008). Other empirical findings report transactional leadership style, or its underlying behaviors, as not predicting continuance commitment, but instead identifying certain sub-scales of transformational leadership as determining this particular dimension of organizational commitment (Lo et al, 2010). Transactional leadership style positively correlated with continuance commitment, which was expected given the theoretical assumption that the follower's perceived psychological-transactional contract with the organization might be the antecedent of continuance commitment (Meyer \& Allen, 1997). Transformational leadership also impacted continuance commitment, but not as strongly as transactional leadership did.

Existing literature and previous studies found that passive/avoidant leadership style either do not correlate or correlate negatively with affective commitment (Limsila \& Ogunlana, 2008; Bučiūnienė \& Škudienè, 2008; Lo et al, 2010). Such leaders are not admired by their followers who, in turn, might tend to assimilate their negative experiences from interaction with the manager to a wider perception of the work place and will most likely not have high levels of emotional attachment to the organization. The findings of this study support the results obtained in previous empirical researches which confirmed that passive/avoidant leadership negatively effects affective commitment (Bučiūnienè \& Škudienè, 2008, Lo et al, 2010).

\section{LIMITATIONS OF THE STUDY}

One possible limitation of the study might be the fact that the questionnaire survey was distributed in the English language to respondents to whom English is not their first language. The respondents might read and comprehend the items differently based on various levels of English language skills. However, this concern is mitigated by the requirement of the organization that employees have English language skills. The lower response rate in the foreign subsidiary might also be considered a limitation. Additionally, this was a sample from one organization, which limits the generalizability of the results.

\section{CONCLUSIONS}

This study examined the relationship between transformational, transactional, and passive/avoidant leadership styles and three dimensions of organizational commitment - affective, continuance, and normative. The key findings revealed that both leadership styles - transformational and transactional - positively affect all dimensions of organizational commitment to varying extents. Meanwhile, passive/avoidant leadership style was found to have a negative effect with affective commitment only. The results of the study confirm earlier findings on the relationship between transformational and transactional leadership styles and affective commitment. In congruence with leadership theory and previous empirical studies, a relationship was also found between transformational leadership style and normative commitment. Also, as supported by existing literature, the effect of transformational leadership on normative commitment is slightly lower when compared to the relationship between transformational leadership style and affective commitment. A relatively new finding reveals transactional leadership style to be a better predictor of continuance commitment confirming the importance of a cost-benefit approach of leadership and mutual economic exchange while previous studies either did not reveal such a relationship or reported correlations that do not vary from the ones with transformational leadership style. Passive/avoidant leadership style, as expected, had a negative effect on affective commitment. 
These findings add to the body of leadership research that has been conducted outside of the U.S. They also confirm previous findings and extend the literature with regard to the relationship between transactional leadership and continuance commitment. The importance of leadership style and organizational commitment is recognized in management literature, and this study examined the relationship between dimensions of these two important constructs.

\section{AUTHOR INFORMATION}

Dr. Sharon Clinebell is a Professor of Management at the Monfort College of Business at the University of Northern Colorado. Her publications have appeared in Journal of Management, Academy of Management Executive, Academy of Management Learning and Education, and Journal of Leadership and Organizational Studies as well as other publications. She is the President of the Academy of Business Education and serves on the editorial boards of the Academy of Management Learning and Education and Quality Management Journal. E-mail: sharon.clinebell@unco.edu

Dr. Vida Škudienė is the Professor of Marketing and Organizational Behaviour at ISM University of Management and Economics, Nagoya University of Commerce and Business, Japan, and Instituto Portugues de Administracao de Marketing (IPAM), Portugal. Prof. Škudienė has presented her research at international conferences in France, Japan, Israel, US (Hawaii, Chicago), Greece, Croatia, France, Spain, Norway, Jamaica, Sweden, Italy (Boccioni), and published over 30 articles, e-textbook on Organizational Behaviour, and co-authored two books on case writing. Prof. Škudienè is a member of editorial advisory board of Baltic Journal of Management. E-mail: vidsku@ism.lt

Renata Trijonytė holds Master degree in International Marketing Management from ISM University of Management and Economics, Lithuania. Her research is focused on employee motivation, leadership and entrepreneurship.

Dr. Reardon is the Chairperson and Professor of Marketing at the Monfort College of Business. His publications have appeared in the Journal of Marketing, Journal of Retailing, Journal of International Marketing, Journal of Marketing Education, among others. He was named the UNC Distinguished Scholar and has been named the Monfort College Scholar five times. In addition, he has been named marketing professor of the year three times. His non-academic background includes managing several businesses in various functions in the Home Shopping, Construction, Casino, and Film industries. E-mail: james.reardon@unco.edu (Corresponding author)

\section{REFERENCES}

1. Allen, N. J. \& Meyer, J. P., (1990). The measurement and antecedents of affective, continuance and normative commitment to organization. Journal of Occupational Psychology, 63, 1-18.

2. Avolio, B. J., Bass, B. M., \& Jung, D.I. (1999). Re-examining the components of transformational and transactional leadership using the Multifactor Leadership Questionnaire. Journal of Occupational and Organizational Psychology, 72, 441-462.

3. Avolio, B. J., Zhu, W., Koh, W., \& Bhatia, P. (2004). Transformational leadership and organizational commitment: Mediating role of psychological empowerment and moderating role of structural distance. Journal of Organizational Behavior, 25(8), 951-968.

4. Bass, B. M. (1990). From transactional to transformational leadership: Learning to share the vision. Organizational Dynamics, 18(3), 19-31.

5. Bass, B. M. (1999). Two decades of research and development in transformational leadership. European Journal of Work and Organization Psychology, 8(1), 9-32.

6. Bass, B. M. \& Avolio, B. J. (1990). The multifactor leadership questionnaire, Palo Alto, CA: Consulting Psychologists Press.

7. Bass, B. M., Avolio, B.J., Jung, D.I., \& Berson Y. (2003). Predicting unit performance by assessing transformational and transactional leadership. Journal of Applied Psychology, 88(2), 207-218.

8. Becker, H. S. (1960). Notes on the concept of commitment. American Journal of Sociology, 66, 32-42. 
9. Boehnke, K., Bontis, N., DiStefano, J.J., \& DiStefano, A.C. Transformational leadership: An examination of cross-national differences and similarities. Leadership \& Organization Development Journal, 24(1), 515.

10. Bučiūnienè, I., \& Škudienè, V. (2008) Impact of Leadership Styles on Employees’ Organizational Commitment in Lithuanian Manufacturing Companies. South East European Journal of Economics and Business, 3(2), 57-65.

11. Dale, K., \& Fox, M. L. (2008) Leadership style and organizational commitment: Mediating effect of role stress. Journal of Managerial Issues, 20(1), 109-130.

12. Dubin, R., Champoux, J. E., \& Porter, L.W. (1975). Central life interests and organizational commitment of blue-collar and clerical workers. Administrative Science Quarterly, 20(3), 411-421.

13. Dunn, M., Dastoor, B., \& Sims, R. (2012). Transformational leadership and organizational commitment: A cross-cultural perspective. Journal of Multidisciplinary Research, 4(1), 45-60.

14. Emery, C. R., \& Barker, K. J. (2007) The effect of transactional and transformational leadership styles on the organizational commitment and job satisfaction of customer contact personnel. Journal of

Organizational Culture, Communications and Conflict, 11(1), 77-90.

15. Flynn, S.I. (2009). Transformational \& transactional leadership. EBSCO Research Starters. Academic Topic Overviews, p. 1-6.

16. Geijsel, F., Sleegers, P., Leithwood, K., \& Jantzi, D. (2003) Transformational leadership effects on teachers' commitment and effort toward school reform. Journal of Educational Administration, 41(3), 228256.

17. Hater, J.J. \& Bass, B. M. (1988). Superiors' evaluations and subordinates' perceptions of transformational and transactional leadership. Journal of Applied Psychology, 73, 695-702.

18. Howell, J. \& Avolio, B. (1993). Transformational leadership, transactional leadership, locus of control, and support for innovation. Journal of Applied Psychology, 78, 891-902.

19. Hunt, J.G. \& Schuler, R. S. (1976). Leader Reward and Sanctions: Behavior Relations Criteria in a Large Public Utility. Carbondale, IL: Southern Illinois Press.

20. Joo, B., Yoon, H., \& Jeung, C. (2012). The effects of core self-evaluations and transformational leadership on organizational commitment. Leadership and Organizational Development Journal, 33, 564-582.

21. Kirkpatrick, S. A. \& Locke, E. A. (1996). Direct and indirect effects of three core charismatic leadership components on performance and attitudes. Journal of Applied Psychology, 81, 36-51.

22. Kleinman, C. (2004). The relationship between managerial leadership behaviors and staff nurse retention. Hospital Topics: Research and Perspectives on Healthcare, 82(4), 2-9.

23. Limsila, K., \& Ogunlana, O. (2008). Performance and leadership outcome correlates of leadership styles and subordinate commitment. Engineering, Construction and Architectural Management, 15(2), 164-184.

24. Lee, J. (2005) Effects of leadership and leader-member exchange on commitment. Leadership \& Organization Development Journal, 26(8), 655-672.

25. Lee, K., Allen, N.J., Meyer, J.P., \& Rhee, K.Y. (2001). The three-component model of organizational commitment: An application to South Korea. Applied Psychology: An International Review, 50(4), 596614.

26. Lo, M.C., Ramayah, T., Min, H.W., \& Songan, P. (2010). The relationship between leadership styles and organizational commitment in Malaysia: Role of leader-member exchange. Asia Pacific Business Review, 16(1-2), 79-103.

27. Lok, P., \& Crawford, J. (1999). The relationship between commitment and organizational culture, subculture, leadership style and job satisfaction in organizational change and development. Leadership \& Organization Development Journal, 20(7), 365-373.

28. Lok, P., \& Crawford, J. (2004). The effect of organizational culture and leadership style on job satisfaction and organizational commitment: A cross-national comparison. Journal of Management Development, 23(4), 321-338.

29. Mathieu, J. E. \& Zajac, D.M. (1990). A review and meta-analysis of the antecedents, correlates and consequences of organizational commitment. Psychological Bulletin, 108(2), 171-194.

30. Medley, F., \& Larochelle, D.R. (1995). Transformational leadership and job satisfaction. Nursing Management, 26(9), 64JJ-64NN.

31. Meyer, J.P. \& Allen, N.J. (1988). Links between work experiences and organizational commitment during the first year of employment: A longitudinal analysis. Journal of Occupational Psychology, 61, 195-209. 
32. Meyer, J.P., \& Allen, N.J. (1991). A three-component conceptualization of organizational commitment. Human Resource Management Review, 1, pp. 61-89.

33. Meyer, J.P., \& Allen, N. J. (1997). Commitment in the work place. London: SAGE Publications.

34. Meyer, J.P., \& Herscovitch, L. (2001). Commitment in the work place: Towards a general model. Human Resource Management Review, 11, 299-326.

35. Mowday, R.T. (1999). Reflections on the study and relevance of organizational commitment. Human Resource Management Review, 8(4), 387-401.

36. Mowday, R.T., Steers, R. M. \& Porter, L. W. 1979. The measurement of organizational commitment. Journal of Vocational Behavior, 14, 224-247.

37. Ozaralli, N. (2003). Effects of transformational leadership on empowerment and team effectiveness. Leadership \& Organization Development Journal, 24(6), 335-344.

38. Podsakoff, P.M., Todor, W.D., Grover, R.A. \& Skov, V.L. (1984). Situational moderators of leader reward and punishment behaviors: Fact or fiction? Organizational Behavior and Human Performance, 34, 21-63.

39. Rehman, S., Shareef, A., Mahmood, A., \& Ishaque, A. (2012). Perceived leadership styles and organizational commitment. Interdisciplinary Journal of Contemporary Research in Business, 4(1), 616626.

40. Rowold, J., \& Rohmann, A. (2009). Relationship between leadership styles and followers' emotional experience and effectiveness in the voluntary sector. Nonprofit and Voluntary Sector Quarterly, 8(2), 270286.

41. Sarros, J.C., \& Santora, J.C. (2001). The transformational-transactional leadership model in practice. Leadership \& Organization Development Journal, 22(8), 383-393.

42. Savery, L.K. (1994). The influence of the perceived styles of leadership of a group of workers on their attitudes to work. Leadership \& Organization Development Journal, 15(4), 12-18.

43. Turner, J. R., \& Müller, R. (2005). The project manager's leadership style as a success factor on projects. A literature review. Project Management Journal, 36(2), 49-61.

44. Yammarino, F. J. \& Bass, B. M. (1990). Long-term forecasting of transformational leadership and its effects among naval officers: In K. E. Clark \& M. B Clark (Eds.), Measures of leadership. West Orange, NJ: Leadership Library of America.

45. Yammarino, F. J. \& Dubinsky, A. J. 1992. Superior-subordinate relationships: A multiple levels of analysis approach. Human Relations, 45(6), 575-601.

46. Yiing, L. H., \& Bin Ahmad, K.Z. (2009). The moderating effects of organizational culture on the relationships between leadership behavior and organizational commitment and between organizational commitment and job satisfaction and performance. Leadership \& Organization Development Journal, $30(1), 53-86$.

47. Yousef, D. (2000). Organizational commitment: A mediator of the relationships of leadership behavior with job satisfaction and performance in a non-western country. Journal of Managerial Psychology, 15(1), 6-28. 


\section{NOTES}

